Supporting Information for:

\title{
a1,4-N-Acetylhexosaminyltransferase EXTL2: the missing link for understanding glycosidic bond biosynthesis with retention of configuration.
}

\author{
Fernanda Mendoza, ${ }^{1,2}$ Hansel Gómez, ${ }^{1,3}$ José M. Lluch $^{1,2}$ and Laura Masgrau ${ }^{1}$ \\ ${ }^{1}$ Institut de Biotecnologia i de Biomedicina (IBB), Universitat Autònoma de Barcelona, 08193 Bellaterra (Cerdanyola del \\ Vallès), Barcelona, Spain. \\ ${ }^{2}$ Departament de Química, Universitat Autònoma de Barcelona, 08193 Bellaterra (Cerdanyola del Vallès), Barcelona, \\ Spain. \\ ${ }^{3}$ Current address: Joint BSC-CRG-IRB Program in Computational Biology, IRB Barcelona, 08028 Barcelona, Spain
}

Corresponding author: Laura.Masgrau@uab.cat 
Table S1. Important distances (in $\AA$ ) for the front-side attack mechanism in EXTL2 modeled using the reaction

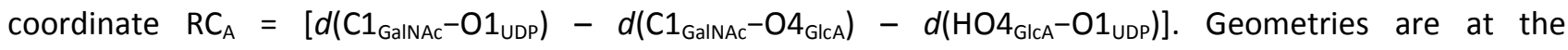
$\mathrm{QM}(\mathrm{BP} 86 / \mathrm{TZVP}) / \mathrm{MM}$ level and atomic charges (q (a.u.)) are at the $\mathrm{QM}=(\mathrm{M} 05-2 \mathrm{X} / \mathrm{TZVP} / / \mathrm{BP} 86 / \mathrm{TZVP}) / \mathrm{MM}$ one. $\mathrm{OS}$ and IP refer to oxocarbenium species and ion pair intermediate, respectively. $\mathrm{R} 1_{\mathrm{A}}$ is the initial Michaelis complex. A second minimum is found along the reaction path $\left(R 2_{A}\right)$ in which the $\mathrm{HO} 4$ atom has reoriented and is now interacting with UDP.

\begin{tabular}{|c|c|c|c|c|c|c|c|}
\hline & $\begin{array}{c}\text { Reactant } \\
\left(\mathbf{R} 1_{A}\right)\end{array}$ & $\begin{array}{l}\text { Reactant } \\
\left(\text { (R2 } 2_{A}\right)\end{array}$ & $O S 1_{A}{ }^{a}$ & $O S 2_{A}{ }^{a}$ & $\mathrm{IP}_{\mathrm{A}}\left[\mathrm{IP}_{\mathrm{B}}\right]^{\mathrm{b}}$ & $\mathrm{TS2}_{\mathrm{A}}$ & $\begin{array}{c}\text { Product } \\
\left(P_{A}\right)\end{array}$ \\
\hline $\mathrm{d}\left(\mathrm{C} 1_{\text {GalNAc }}-01_{\text {UDP }}\right)$ & 1.50 & 1.54 & 2.29 & 2.77 & $3.50[3.53]$ & 3.56 & 3.62 \\
\hline $\mathrm{d}\left(\mathrm{C} 1_{\text {GalNAc }}-05_{\text {GalNAc }}\right)$ & 1.39 & 1.37 & 1.28 & 1.27 & $1.28[1.28]$ & 1.30 & 1.39 \\
\hline$d\left(C 1_{\text {GalNAc }}-04_{G \mid c A}\right)$ & 3.04 & 2.99 & 2.84 & 2.76 & $2.43[2.43]$ & 2.01 & 1.51 \\
\hline $\mathrm{d}\left(\mathrm{OD} 1_{\mathrm{D} 246}-\mathrm{C} 1_{\text {GalNAc }}\right)$ & 5.43 & 5.34 & 4.86 & 4.60 & $4.16[3.16]$ & 3.40 & 4.41 \\
\hline $\mathrm{d}\left(\mathrm{HO}_{\mathrm{GICA}}-\mathrm{O} 1_{\text {UDP }}\right)$ & 3.27 & 2.04 & 1.71 & 1.64 & $1.56[1.57]$ & 1.38 & 1.02 \\
\hline$d\left(\mathrm{HO}_{\mathrm{GICA}}-\mathrm{O} 4_{\mathrm{GICA}}\right)$ & 1.01 & 0.98 & 1.01 & 1.01 & $1.03[1.02]$ & 1.09 & 1.60 \\
\hline$d\left(\right.$ W604-O2B $\left.B_{\text {UDP }}\right)$ & 1.81 & 1.86 & 1.73 & 1.67 & $1.61[1.60]$ & 1.61 & 1.66 \\
\hline $\mathrm{d}\left(\mathrm{HN} 2^{\prime}{ }_{\text {GalNAc }}-\mathrm{O} 3_{\text {GlcA }}\right)$ & 2.50 & 2.37 & 2.10 & 2.03 & $1.76[1.77]$ & 1.76 & 1.82 \\
\hline $\mathrm{d}\left(\mathrm{O} \mathrm{B}_{\mathrm{GaINAc}}-\mathrm{HO}_{\mathrm{GlcA}}\right)$ & 1.72 & 1.72 & 1.63 & 1.61 & $1.60[1.60]$ & 1.63 & 1.81 \\
\hline $\mathrm{d}\left(\mathrm{NH} 2_{\mathrm{R} 293}-\mathrm{O} 6_{\mathrm{GalNAC}}\right)$ & 3.72 & 3.65 & 3.57 & 3.48 & $3.13[3.08]$ & 2.97 & 2.87 \\
\hline $\mathrm{d}\left(\mathrm{NE}_{\mathrm{R} 293}-\mathrm{O} 6 \mathrm{~B}_{\mathrm{GlCA}}\right)$ & 3.20 & 3.20 & 3.23 & 3.19 & $3.17[3.19]$ & 3.05 & 2.95 \\
\hline $\mathrm{d}\left(\mathrm{NH}_{\mathrm{R} 293}-\mathrm{O} 6 \mathrm{~B}_{\mathrm{Gl} \mathrm{CA}}\right)$ & 3.45 & 4.16 & 4.21 & 4.17 & $4.19[4.08]$ & 3.98 & 3.84 \\
\hline $\mathrm{q}(\mathrm{C} 1+\mathrm{H} 1+\mathrm{O} 5)_{\text {GalNAc }}$ & 0.13 & 0.15 & 0.47 & 0.50 & $0.46[0.47]$ & 0.36 & 0.09 \\
\hline$\varphi, \theta^{c}$ & $\begin{array}{c}206.5 \\
14.3\end{array}$ & $\begin{array}{l}206.3 \\
18.5\end{array}$ & $\begin{array}{c}226.4 \\
32.9\end{array}$ & $\begin{array}{c}229.2 \\
41.6\end{array}$ & $\begin{array}{c}229.4[229.5] \\
44.4[44.4]\end{array}$ & $\begin{array}{c}226.5 \\
36.3\end{array}$ & $\begin{array}{c}213.0 \\
21.1\end{array}$ \\
\hline
\end{tabular}

\footnotetext{
${ }^{a}$ These structures were optimized as transition states. Nevertheless, we were not able to obtain any imaginary frequency but only small frequencies for the vibrations associated with the $\mathrm{O} 1_{\mathrm{UDP}}-\mathrm{C} 1_{\text {GalNAc }}$ bond breakage (see Table S3).

b When optimizing at the BP86/TZVP level of theory two IPs were found. In one of them $\left(\mathrm{IP}_{\mathrm{B}}\right)$, Asp246 had rotated a little bit as compared to its orientation in reactants and, as a result, it stayed closer to the anomeric centre.

${ }^{c}$ When $\phi$ and $\theta$ take the values of 210.0 and 54.70 , respectively, the sugar is in an envelope $\left({ }^{4} \mathrm{E}\right)$ conformation. On the other hand, when $\phi$ and $\theta$ take the values of $240.0^{\circ}$ and $50.8^{\circ}$, respectively, the ring is a half-chair $\left({ }^{4} \mathrm{H}_{3}\right)$ conformation.
} 
(a)

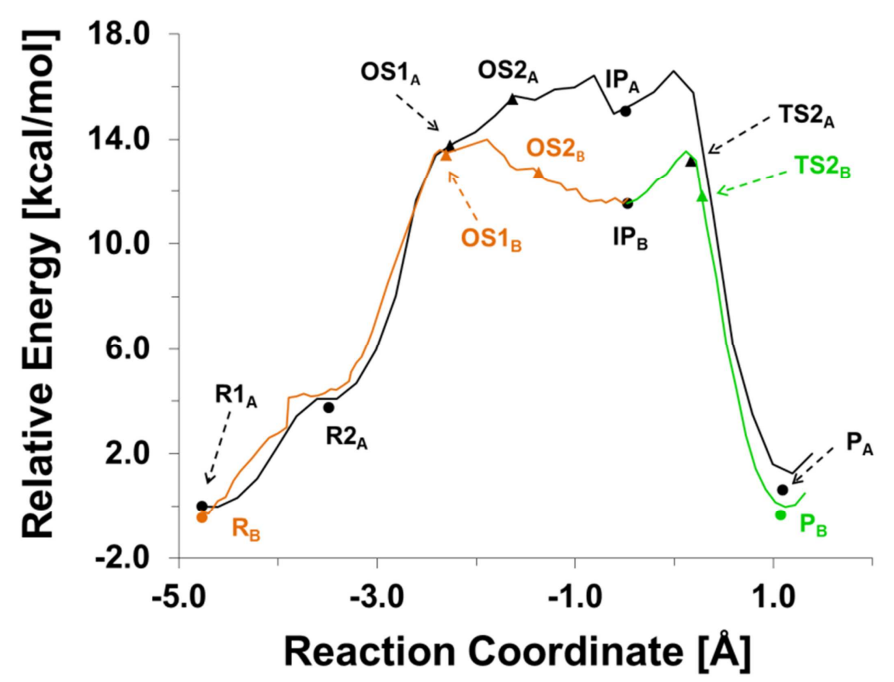

(b)

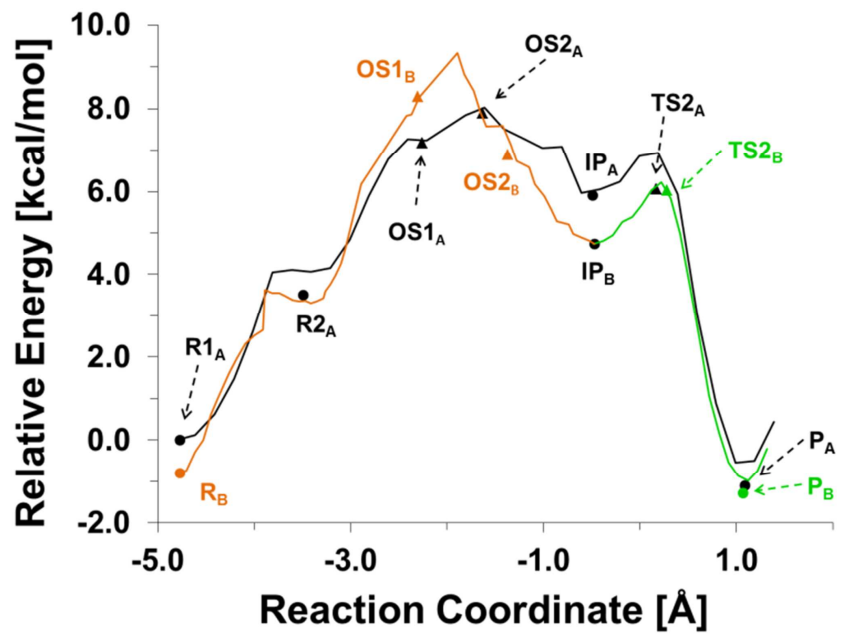

Figure S1. QM/MM scan calculation plots for the front-side mechanism using: a reaction coordinate defined as $R C_{A}=\left[d\left(C 1_{\text {GalNAc }}-O 1_{U D P}\right)-d\left(C_{G_{G a l N A c}}-O 4_{G I C A}\right)-d\left(H O 4_{G l C A}-O 1_{U D P}\right)\right]$, with $R 1_{A}$ as starting point, black color; a $R C$ defined as $\mathrm{RC}=\left[d\left(\mathrm{C}_{\mathrm{GalNAC}}-\mathrm{O} 4_{\mathrm{GICA}}\right)-d\left(\mathrm{C}_{\mathrm{GaINAC}}-01_{\mathrm{UDP}}\right)-d\left(\mathrm{HO}_{\mathrm{GICA}}-\mathrm{O} 6 \mathrm{~B}_{\mathrm{GICA}}\right)\right]$, with $\mid \mathrm{P}_{\mathrm{B}}$ as starting point and going to reactants, $R_{B}$, orange color; and the path connecting with $I P_{B}$ with the products, $P_{B}$, green color. Note that $R_{B}$ is only structurally slightly different from $R 1_{A}$. The circles are used to indicate the location of optimized minima; the triangles indicate stationary points localized in the transition state search (although the frequency analysis did not provide with an imaginary frequency, except in the case of $\mathrm{TS}_{\mathrm{B}}$; see Table S3). The levels of theory are (a) QM=(M05-2X//BP86/TZVP) and (b) QM=BP86/TZVP. 
Table S2. . Important distances (in $\AA$ ) for the front-side attack mechanism in EXTL2 modeled from the IP intermediate towards reactants $\left(R_{B}\right)$ and products $\left(P_{B}\right)$. Geometries are at the $Q M(B P 86 / T Z V P) / M M$ level and atomic charges (q (a.u.)) are at the $\mathrm{QM}=(\mathrm{M} 05-2 \mathrm{X} / \mathrm{TZVP} / / \mathrm{BP} 86 / \mathrm{TZVP}) / \mathrm{MM}$ one. OS and IP refer to oxocarbenium species and ion pair intermediate, respectively (see Table S3).

\begin{tabular}{|c|c|c|c|c|c|c|}
\hline & Reactant $\left(R_{B}\right)$ & $\operatorname{OS1} 1_{B}{ }^{a}$ & $O S 2_{B}{ }^{a}$ & $\mathbf{I P}_{\mathrm{B}}$ & $\mathrm{TS2}_{\mathrm{B}}$ & Product $\left(P_{B}\right)$ \\
\hline $\mathrm{d}\left(\mathrm{C} 1_{\text {GalNAc }}-\mathrm{O} 1_{\text {UDP }}\right)$ & 1.50 & 2.28 & 3.02 & 3.53 & 3.56 & 3.60 \\
\hline $\mathrm{d}\left(\mathrm{C} 1_{\text {GalNAc }}-\mathrm{O} 5_{\text {GalNAC }}\right)$ & 1.38 & 1.28 & 1.27 & 1.28 & 1.31 & 1.39 \\
\hline $\mathrm{d}\left(\mathrm{C} 1_{\text {GalNAc }}-\mathrm{O} 4_{\mathrm{GlCA}}\right)$ & 3.03 & 2.86 & 2.74 & 2.43 & 1.90 & 1.51 \\
\hline $\mathrm{d}\left(\mathrm{OD} 1_{\mathrm{D} 246}-\mathrm{C} 1_{\mathrm{GaINAC}}\right)$ & 5.34 & 3.85 & 3.21 & 3.16 & 3.50 & 4.09 \\
\hline $\mathrm{d}\left(\mathrm{HO}_{\mathrm{GICA}}-\mathrm{O} 1_{\mathrm{UDP}}\right)$ & 3.24 & 1.72 & 1.65 & 1.57 & 1.33 & 1.02 \\
\hline $\mathrm{d}\left(\mathrm{HO}_{\mathrm{GICA}}-\mathrm{O} 4_{\mathrm{GlCA}}\right)$ & 1.00 & 1.00 & 1.00 & 1.02 & 1.11 & 1.59 \\
\hline $\mathrm{d}\left(\right.$ WAT604-O2B $\left.\mathrm{B}_{\text {UDP }}\right)$ & 1.80 & 1.73 & 1.63 & 1.60 & 1.63 & 1.67 \\
\hline $\mathrm{d}\left(\mathrm{HN2}{ }_{\text {GalNAc }}-\mathrm{O}_{\mathrm{GlCA}}\right)$ & 2.49 & 2.03 & 1.89 & 1.77 & 1.75 & 1.82 \\
\hline $\mathrm{d}\left(\mathrm{O} \mathrm{B}_{\mathrm{GaINAc}}-\mathrm{HO}_{\mathrm{GICA}}\right)$ & 1.71 & 1.64 & 1.62 & 1.60 & 1.63 & 1.81 \\
\hline $\mathrm{d}\left(\mathrm{NH} 2_{\mathrm{R} 293}-\mathrm{O} 6_{\mathrm{GaINAC}}\right)$ & 3.72 & 3.53 & 3.36 & 3.08 & 2.95 & 2.86 \\
\hline $\mathrm{d}\left(\mathrm{NH} 2_{\mathrm{R} 293}-\mathrm{C} 1_{\text {GalNAC }}\right)$ & 3.63 & 3.45 & 3.45 & 3.61 & 3.76 & 3.97 \\
\hline $\mathrm{d}\left(\mathrm{NH} 2_{\mathrm{R} 293}-\mathrm{O} 5_{\mathrm{GaINAc}}\right)$ & 3.03 & 2.94 & 2.89 & 2.89 & 2.91 & 2.98 \\
\hline $\mathrm{d}\left(\mathrm{HH} 22_{\mathrm{R} 293^{-}}-\mathrm{OD} 2_{\mathrm{D} 246}\right)$ & 1.78 & 1.85 & 1.85 & 1.85 & 1.82 & 1.80 \\
\hline $\mathrm{d}\left(\mathrm{HH} 12_{\mathrm{R} 293^{-}}-\mathrm{OD} 1_{\mathrm{D} 246}\right)$ & 1.64 & 1.69 & 1.75 & 1.75 & 1.72 & 1.68 \\
\hline $\mathrm{d}\left(\mathrm{NE}_{\mathrm{R} 293}-\mathrm{O} \mathrm{B}_{\mathrm{GlCA}}\right)$ & 3.24 & 3.34 & 3.31 & 3.19 & 3.02 & 2.93 \\
\hline $\mathrm{d}\left(\mathrm{NH} 1_{\mathrm{R} 293}-06 \mathrm{~B}_{\mathrm{GlCA}}\right)$ & 3.40 & 4.27 & 4.27 & 4.08 & 3.90 & 3.70 \\
\hline $\mathrm{d}\left(\mathrm{HH} 21_{\mathrm{R} 293}-\mathrm{OD} 1_{\mathrm{Asn} 243}\right)$ & 2.03 & 2.01 & 1.98 & 1.99 & 2.06 & 2.13 \\
\hline $\mathrm{d}\left(\mathrm{HH} 11_{\mathrm{R} 293}-\mathrm{OH}_{\mathrm{Y} 193}\right)$ & 1.98 & 1.91 & 1.90 & 1.88 & 1.89 & 1.90 \\
\hline $\mathrm{d}\left(\mathrm{HH}_{\mathrm{Y} 193}-\mathrm{O} 6 \mathrm{~A}_{\mathrm{GlCA}}\right)$ & 1.79 & 1.71 & 1.70 & 1.71 & 1.72 & 1.75 \\
\hline $\mathrm{d}\left(\mathrm{HE}_{\mathrm{R} 181}-\mathrm{O} \mathrm{AA}_{\mathrm{GlCA}}\right)$ & 1.72 & 1.69 & 1.69 & 1.70 & 1.69 & 1.70 \\
\hline $\mathrm{d}\left(\mathrm{HH} 21_{\mathrm{R} 181}-\mathrm{O} 5_{\mathrm{GlCA}}\right)$ & 1.74 & 1.76 & 1.77 & 1.80 & 1.82 & 1.84 \\
\hline $\mathrm{q}(\mathrm{C} 1+\mathrm{H} 1+\mathrm{O} 5)_{\mathrm{GalNAC}}$ & 0.14 & 0.48 & 0.50 & 0.47 & 0.32 & 0.10 \\
\hline$\varphi, \theta^{c}$ & $209.3,13.5$ & $222.9,32.6$ & $226.6,44.8$ & $229.5,44.4$ & $226.7,32.5$ & $212.2,21.7$ \\
\hline
\end{tabular}

${ }^{a}$ These structures were optimized as transition states. Nevertheless, we were not able to obtain an imaginary frequency for them but a small real frequency for the vibration associated with the $\mathrm{O}_{1 \mathrm{UDP}}-\mathrm{C} 1_{\text {GalNAc }}$ bond breakage (see Table S3). 
Table S3. QM/MM potential energy (V) relative to the corresponding reactants structure, for oxocarbenium species (OS) that could correspond to transition states of the glycosidic bond breakage process, for the IP intermediate, for the transition state corresponding to acceptor substrate attack and for the one corresponding to Asp246 attack. $v$ is the lowest harmonic vibrational frequency, in $\mathrm{cm}^{-1}$, obtained for each stationary point.

\begin{tabular}{c|c|c|c}
\hline Structure & $\mathrm{V}(\mathrm{QM}=\mathrm{BP86} / \mathrm{TZVP})$ & $\mathrm{V}(\mathrm{QM}=\mathrm{M} 05-2 \mathrm{X} / / \mathrm{BP} 86 / \mathrm{TZVP})$ & $\mathrm{N}$ \\
\hline $\mathrm{OS}_{\mathrm{A}}$ & 7.18 & 13.75 & $56.40^{\mathrm{a}}$ \\
$\mathrm{OS} 2_{\mathrm{A}}$ & 7.89 & 15.51 & $56.84^{\mathrm{a}}$ \\
$\mathrm{IP} \mathrm{A}_{\mathrm{A}}$ & 5.90 & 15.08 & $>65.00^{\mathrm{b}}$ \\
$\mathrm{TS} 2_{\mathrm{A}}$ & 6.06 & 13.17 & $47.61^{\mathrm{c}}$ \\
\hline $\mathrm{OS}_{\mathrm{B}}$ & 9.08 & 13.86 & $53.31^{\mathrm{a}}$ \\
$\mathrm{OS}_{\mathrm{B}}$ & 7.70 & 13.17 & $60.87^{\mathrm{a}}$ \\
$\mathrm{IP} \mathrm{P}_{\mathrm{B}}$ & 5.54 & 12.00 & $>67.00^{\mathrm{b}}$ \\
$\mathrm{TS}_{\mathrm{B}}$ & 6.82 & 12.28 & $85.41 i^{\mathrm{c}}$ \\
\hline $\mathrm{OS}_{\mathrm{C}}$ & 6.34 & 11.28 & $53.11^{\mathrm{a}}$ \\
$\mathrm{OS}_{\mathrm{C}}$ & 6.04 & 12.50 & $55.57^{\mathrm{a}}$ \\
$\mathrm{IP}_{\mathrm{C}}$ & 5.15 & 11.12 & $>80.00^{\mathrm{b}}$ \\
$\mathrm{TS}_{\mathrm{CGE}}$ & 15.31 & 17.80 & $70.76 i^{\mathrm{d}}$ \\
\hline
\end{tabular}

${ }^{a}$ The smallest frequency of this stationary point is related with a vibrational motion involving $C 1_{\text {GalNAc }}$ and $01_{\text {UDP }}$, thus representing the glycosidic bond breakage.

${ }^{b}$ The lowest calculated frequency for $\mathrm{IP}_{\mathrm{A}}$ and $\mathrm{IP}_{\mathrm{B}}$ were larger than 65 and $67 \mathrm{~cm}^{-1}$, respectively. Moreover, they are not associated with any vector involved with the forming/breakage of chemical bonds. Instead, they correspond to a horizontal movement of the ring without approaching the anomeric carbon to any of the three possible attacking oxygens, $\mathrm{O} 1_{\mathrm{UDP}}, \mathrm{OD} 1_{\mathrm{D} 246}$ or $\mathrm{O} 4_{\mathrm{GICA}}$.

c This frequency is associated with a ring movement that brings the anomeric carbon closer to the attacking $\mathrm{O}_{\mathrm{GICA}}$.

${ }^{d}$ This imaginary frequency is associated with the $C 1_{\text {GalNAc }}-O D 1_{D 246}$ bond formation. 


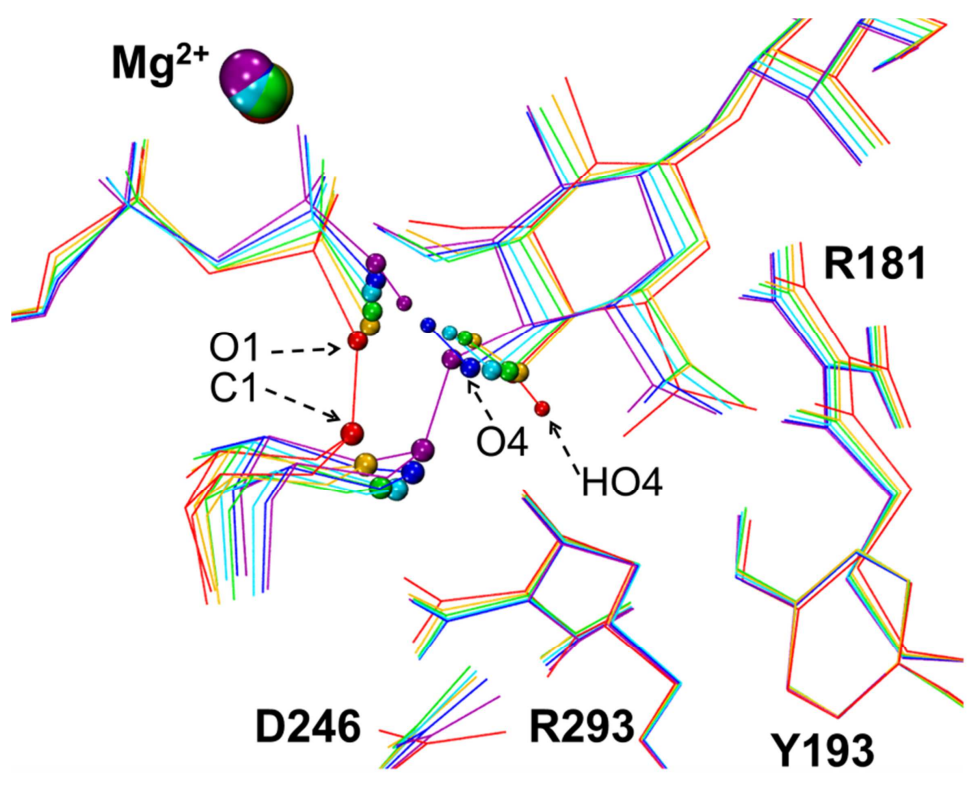

Figure S2. Representation of the main structures localized in this work along the front-side attack pathway B.

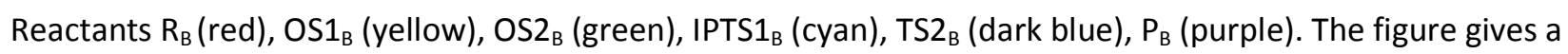
general view of the basic atomic rearrangements that may happen during GalNAc transfer.

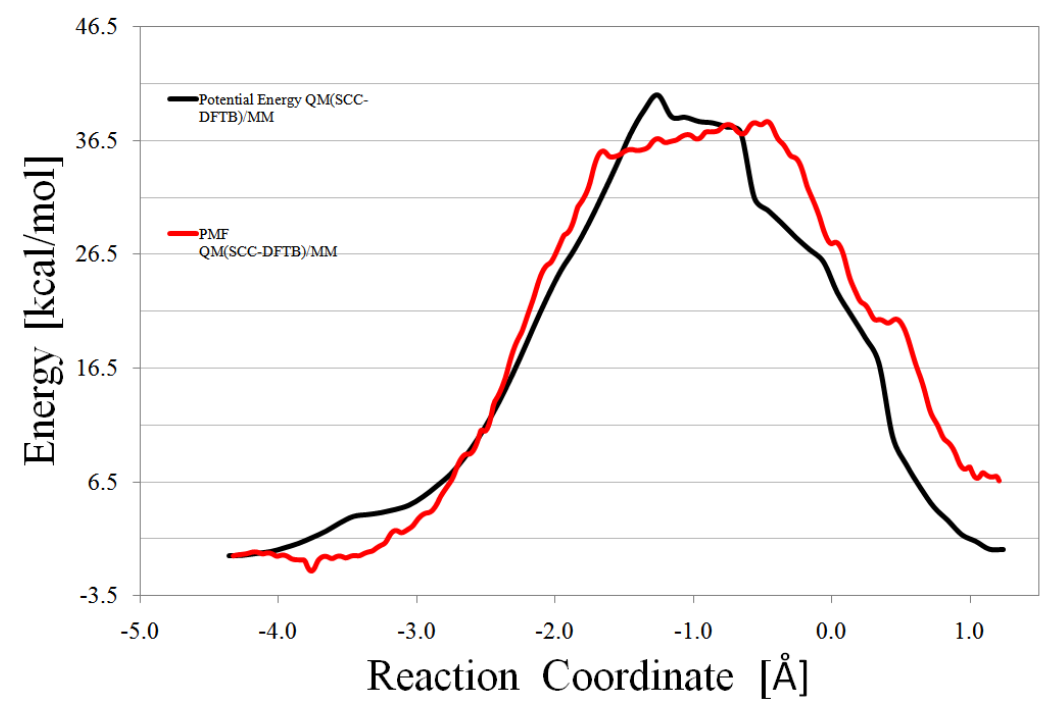

Figure S3. Calculated potential energy (black line) and free energy profile (red line) for the front-side mechanism at the QM(SCC-DFTB)/MM level of theory. The reactants are located on the left side of the graph. Energies are given in $\mathrm{kcal} / \mathrm{mol}$, the reaction coordinate $\left(\mathrm{RC}_{\mathrm{A}}\right.$ defined above) in $\AA$. 
Table S4. Important distances (in $\AA$ ) for $Q M / M M$ optimized structures along the Asp246 attack to form the CGE. Geometries are at the QM(BP86/TZVP)/MM level and atomic charges (q (a.u.)) are at the QM=(M052X/TZVP//BP86/TZVP)/MM one. OS and IP refer to oxocarbenium species and ion pair intermediate, respectively (see Table S3).

For going from reactants $\left(R 1_{A}\right)$ to the $C G E$, the reaction coordinate used was $R C_{D A}=\left[d\left(C 1_{G a l N A c}-O 1_{U D P}\right)-\right.$ $\left.d\left(\mathrm{C1}_{\text {GalNAc }}-\mathrm{OD} 1_{\mathrm{Asp246}}\right)-d\left(\mathrm{HO}_{\mathrm{GICA}}-\mathrm{O} 1_{\text {GalNAc }}\right)\right]$, which includes $\mathrm{HO}_{\mathrm{GlCA}}$. The location of the optimized CGE (see Figure S2) showed that this coordinate may not be adequate for modeling the reaction path from $\mathrm{IP}_{\mathrm{C}}$ to CGE. Thus, starting at $C G E$, a new reaction path towards $I P_{C}$ was calculated. A structure from this path was used to localize $\mathrm{TS}_{\mathrm{CGE}}$. See Figure S3.

\begin{tabular}{|c|c|c|c|c|c|c|}
\hline & $\mathbf{R} \mathbf{1}_{\mathrm{A}}$ & $O S 1_{c}^{a}$ & $0 S 2_{c}^{a}$ & $\mathbf{I P} \mathbf{P}_{\mathrm{c}}$ & $\mathrm{TS}_{\mathrm{CGE}}$ & CGE \\
\hline $\mathrm{d}\left(\mathrm{C} 1_{\text {GalNAc }}-01_{\text {UDP }}\right)$ & 1.50 & 2.29 & 2.94 & 3.30 & 3.87 & 4.16 \\
\hline $\mathrm{d}\left(\mathrm{C} 1_{\text {GalNAc }}-\mathrm{O} 5_{\text {GalNAc }}\right)$ & 1.39 & 1.28 & 1.27 & 1.27 & 1.33 & 1.37 \\
\hline $\mathrm{d}\left(\mathrm{C} 1_{\mathrm{GaINAc}}-\mathrm{O} 4_{\mathrm{GlCA}}\right)$ & 3.04 & 2.87 & 2.72 & 2.61 & 2.98 & 3.14 \\
\hline $\mathrm{d}\left(\mathrm{OD} 1_{\mathrm{D} 246}-\mathrm{C} 1_{\text {GalNAC }}\right)$ & 5.43 & 3.92 & 3.49 & 3.05 & 1.79 & 1.59 \\
\hline $\mathrm{d}\left(\mathrm{HO}_{\mathrm{GICA}}-\mathrm{O} 1_{\mathrm{UDP}}\right)$ & 3.27 & 1.71 & 1.66 & 1.59 & 1.68 & 1.68 \\
\hline $\mathrm{d}\left(\mathrm{HO}_{\mathrm{Gl|CA}}-\mathrm{O} 4_{\mathrm{GlCA}}\right)$ & 1.01 & 1.00 & 1.02 & 1.02 & 1.01 & 1.01 \\
\hline$d\left(W 604-02 B_{U D P}\right)$ & 1.79 & 1.74 & 1.66 & 1.63 & 1.63 & 1.63 \\
\hline $\mathrm{d}\left(\mathrm{HN} 2^{\prime}{ }_{\text {GalNAc }}-\mathrm{O} 3_{\mathrm{GlCA}}\right)$ & 2.52 & 2.11 & 1.86 & 1.79 & 1.96 & 1.99 \\
\hline $\mathrm{d}\left(\mathrm{O3B}_{\mathrm{GalNAc}}-\mathrm{HO}_{\mathrm{GlcA}}\right)$ & 1.72 & 1.63 & 1.60 & 1.59 & 1.57 & 1.57 \\
\hline $\mathrm{d}\left(\mathrm{NH} 2_{\mathrm{R} 293}-\mathrm{O} 6_{\text {GalNAc }}\right)$ & 3.71 & 3.58 & 3.37 & 3.19 & 2.97 & 3.03 \\
\hline $\mathrm{d}\left(\mathrm{NE}_{\mathrm{R} 293}-\mathrm{O} \mathrm{B}_{\mathrm{GlCA}}\right)$ & 3.23 & 3.27 & 3.23 & 3.19 & 3.01 & 2.99 \\
\hline $\mathrm{d}\left(\mathrm{NH}_{\mathrm{R} 293}-\mathrm{O} 6 \mathrm{~B}_{\mathrm{GlCA}}\right)$ & 3.44 & 4.21 & 4.21 & 4.17 & 3.92 & 3.84 \\
\hline $\mathrm{q}(\mathrm{C} 1+\mathrm{H} 1+\mathrm{O} 5)_{\mathrm{GalNAc}}$ & 0.13 & 0.48 & 0.50 & 0.50 & 0.23 & 0.10 \\
\hline$\varphi, \theta$ & $\begin{array}{c}206.5 \\
14.3\end{array}$ & $\begin{array}{c}228.6 \\
32.9\end{array}$ & $\begin{array}{c}232.6 \\
44.6\end{array}$ & $\begin{array}{r}233.2 \\
, 47.4\end{array}$ & $\begin{array}{c}248.9 \\
57.0\end{array}$ & $\begin{array}{c}252.7 \\
60.0\end{array}$ \\
\hline
\end{tabular}

a These structures were optimized as transition states. Nevertheless, we were not able to obtain any imaginary frequency but the smallest real frequency is associated with the $\mathrm{O}_{1 \mathrm{UDP}}-\mathrm{C} 1_{\text {GalNAc }}$ bond breakage (See Table S3). 
(a)

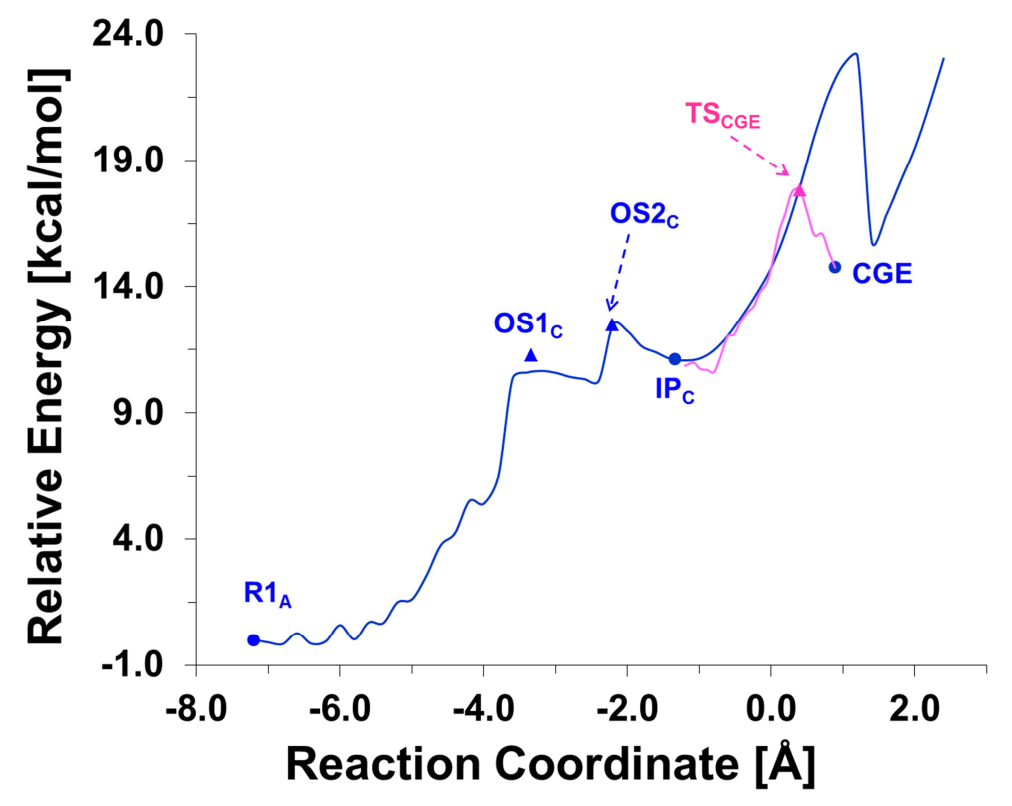

(b)

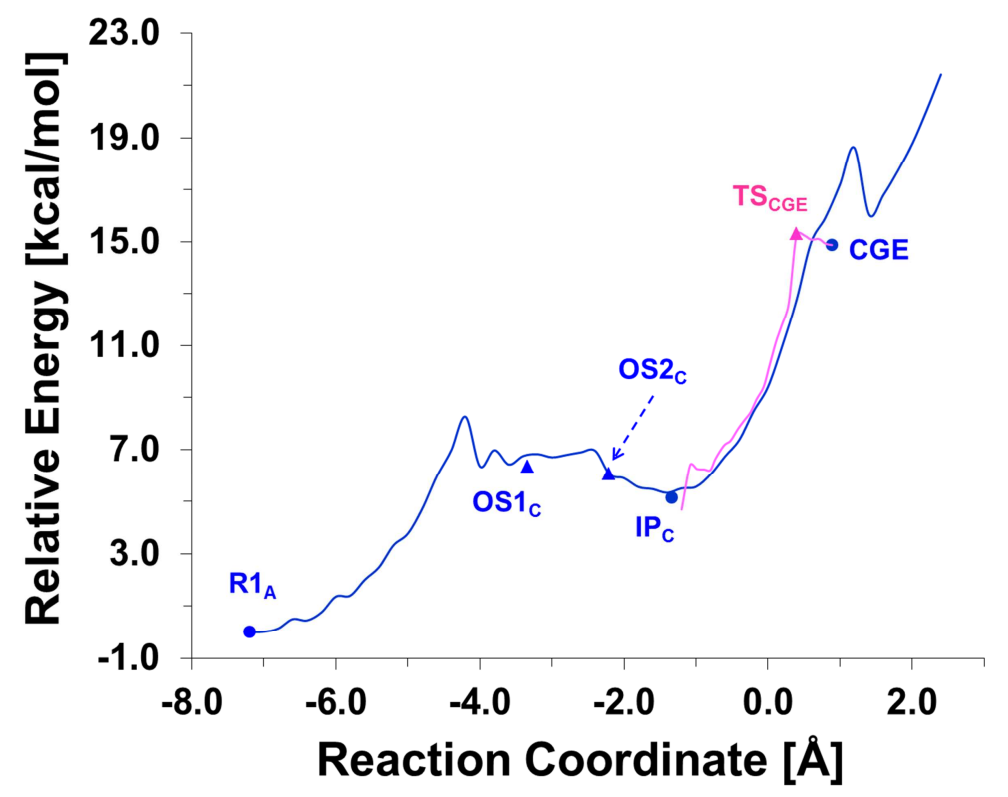

Figure S4. $\mathrm{QM} / \mathrm{MM}$ scan calculation plots for the Asp246 attack using: a reaction coordinate defined as $\mathrm{RC}_{\mathrm{DA}}=$ $\left[\mathrm{d}\left(\mathrm{C1}_{\text {GalNAc }}-\mathrm{O} 1_{\mathrm{UDP}}\right)-\mathrm{d}\left(\mathrm{C} 1_{\text {GalNAc }}-\mathrm{OD} 1_{\mathrm{Asp246}}\right)-\mathrm{d}\left(\mathrm{HO}_{\mathrm{GlCA}}-\mathrm{O} 1_{\mathrm{UDP}}\right)\right]$, with $\mathrm{R} 1_{\mathrm{A}}$ as starting point, blue color; a reaction coordinate defined as $\mathrm{RC}=\left[d\left(\mathrm{C} 1_{\mathrm{GaINAc}}-\mathrm{OD} 1_{\mathrm{Asp246}}\right)-d\left(\mathrm{C} 1_{\mathrm{GalNAc}}-\mathrm{O} 1_{\mathrm{UDP}}\right)\right]$, with $\mathrm{CGE}$ as starting point, pink color. The circles are used to indicate the location of optimized minima; the triangles indicate stationary points localized in the transition state search (although the frequency analysis did not provide with an imaginary frequency, except in the case of TS2 ${ }_{\text {CGE; }}$ see Table S3). The levels of theory are (a) QM=(M05-2X//BP86/TZVP) and (b) $\mathrm{QM}=\mathrm{BP} 86 / \mathrm{TZVP}$. 


\section{Sequence analysis of family GT64}

Gene bank codes for all proteins in family GT64 where extracted from the CAZy database $[1,2]$ and used to download their corresponding sequences from NCBI. A multiple alignment was performed aligning all this sequences against this family Hidden Markov Model (HMM) profile downloaded from the PFAM $[3,4]$ database (Glyco_transf_64, PF09258.6) using the "hmmaling" program from the HMMER version 3 package [5]. The generated alignment was loaded in jalview [6] for inspection and analysis of the required alignment positions.

In the CAZy database, the GT64 family includes 125 proteins, with 31 of these sequences being just fragments. We have performed the sequence alignment of the remaining 94 members (thus fragments have been excluded).

The Asp at this position (Asp246 in EXTL2) is conserved in all but one member of the family (EXTL1 protein [Bos taurus]), in which case a Glu is found.

The Arg293 in EXTL2 is conserved in this position in 88 out of the 94 members. In particular, it is not conserved in the following cases: (amino acid found is indicated in each case)

>gi|7407104|gb |AAF61913.1|AF224461_1/1-669 multiple exostoses-like 1 protein [Mus musculus]

D

>gi|380810494 |gb|AFE77122.1|/1-675 exostosin-like 1 [Macaca mulatta]

A

$>$ gi|55727720|emb |CAH90611.1|/1-640 hypothetical protein [Pongo abelii]

A

$>$ gi|1524413|gb|AAC51141.1|/1-676 multiple exostosis-like protein [Homo sapiens]

A

$>$ gi|151556262 |gb|AAl50062.1|/1-675 EXTL1 protein [Bos taurus]

A

$>$ gi|195613954|gb|ACG28807.1|/1-737 hypothetical protein [Zea mays]

>gi|238661051|emb|CAZ32036.1|/1-1001 exostosin-2, putative [Schistosoma mansoni]

\section{References}

[1] The Carbohydrate Active Enzymes database. http://www.cazy.org (accessed Nov 2, 2015)

[2] Lombard, V.; Golaconda Ramulu, H.; Drula, E.; Coutinho, P.M.; Henrissat, B. Nucleic Acids Res., 2014, 42, D490-D495.

[3] Finn, R.D.; Bateman, A.; Clements, J.; Coggill, P.; Eberhardt, R. Y.; Eddy, S. R.; Heger, A.; Hetherington, K.; Holm, L.; Mistry, J.; Sonnhammer, E. L. L.; Tate, J.; Punta, M. Nucleic Acids Res., 2013, 42, D222-D230.

[4] The European Bioinformatics Institute (EMBL-EBI). http://pfam.sanger.ac.uk (accessed Nov 2, 2015).

[5] Mistry, J.; Finn, R. D.; Eddy, S.R.; Bateman, A.; Punta, M. Nucleic Acids Res., 2013, 41, e121.

[6] Waterhouse, A. M.; Procter, J. B.; Martin, D. M. A.; Clamp, M.; Barton, G. J. Bioinformatics, 2009, 25, 11891191. 